\title{
Grazing Effects on Mycorrhizal Coloniza- tion and Floristic Composition of the Vegeta- tion on a Semiarid Range in Northern Nevada
}

\author{
GABOR J. BETHLENFALVAY AND SUREN DAKESSIAN
}

\begin{abstract}
The effect of grazing on the colonization of range plants by vesicular-arbuscular mycorrhizal (VAM) fungi was investigated within an exclosure and on degraded Wyoming big sagebrush (Artemisia tridentata ssp. wyomingensis) rangelands at Medell Flat, near Reno, Nev. Implications of the interaction between mycorrhizae and grazing, relevant to the ecology and management of rangelands, are discussed. Density of forage grasses and their colonization by VAM fungi was significantly reduced as a result of grazing, in some cases by more than $50 \%$. No differences in colonizution were found in forage or nonforage broadleaf plants. A significant shift in the floristic composition and density of range plants occurred as a result of the presence or absence of grazing pressure. The decrease in VAM-fungal colonization of grasses under grazing is ascribed to a decrease in leaf areas and an increase in root to shoot ratios-conditions which result in decreased source capacity and increased sink demand.

The interactions between vesicular-arbuscular mycorrhizal (VAM) fungi, their host plants, and the soil are complex (Mosse 1973) and little known in semiarid rangelands (Trappe 1981). Plants benefit from their VAM-fungal endophyte when available $P$ in the soil is limiting (Mosse 1973) and within a certain concentra-

The authors are presently research plant physiologist and soil scientist, U.S. Department of Agriculture, Agricultural Research Service, Western Regional Research Center, Berkeley, Calif. 94710 .

The authors wish to thank R.E. Eckert, R.A. Evans, and J.A. Young, Pasture and Range Management Research, Renewable Resource Center, U.S. Department of Agriculture, Agricultural Research Service, Reno, Nev., for providing facilities, help. and advice for this work; and C. Walker, Forestry Commission, Northern Research Station, Roslin, Midlothian, Scotland, for verification and identification of VAMfungal species.

Manuscript received March 30, 1983.
\end{abstract}

tion range (Bethlenfalvay et al. 1983). Under these conditions the endophyte enhances $P$ uptake to the host (mycotrophy). At higher or lower $P$ concentrations, VAM fungi may act as parasites and may contribute to the growth depression observed in range plants under certain levels of $P$ availability (Hays et al. 1982, Lorenz 1970). As these fungi are obligate biotrophs, they are entirely dependent on their host plants as a source of energy (Snellgrove et al. 1982). Any factor affecting photosynthesis will therefore affect the VAM fungal symbiont (Allen et al. 1981, Daft and El-Giahmi 1978, Trappe 1981). However, the effects of grazing on VAM fungi are little known (Davidson and Christensen 1977, Wallace 1981), and the influence of these symbionts on the tolerance of plants to grazing stress is unknown (Reece and Bonham 1978). This gap in our knowledge of the mechanisms of relationship between mycorrhizal colonization and grazing has added significance, since VAM fungi appear to play a role in soil aggregation and stabilization (Jehne and Thompson 1981, Sutton and Sheppard 1976). These are important problems in the management of lands under cultural stress in arid climates (Cannell and Weeks 1979).

The purpose of this study was to determine grazing effects on VAM fungal colonization of range plants in a heavily grazed Wyoming big sagebrush (Artemisia tridentata ssp. wyomingensis) community.

\section{Materials and Methods}

\section{Study Area}

The survey was conducted at Medell Flat, $35 \mathrm{~km}$ north of Reno, $\mathrm{Nev}$, in a $20-30 \mathrm{~cm}$ precipitation zone at $1,600 \mathrm{~m}$ elevation. Rainfall in the spring preceding the survey was approximately $7 \mathrm{~cm}$. The study area was burned by wildfire 25 years ago and it is now 
dominated by cheatgrass (Bromus tectorum) and other herbaceous species. Some native perennial grasses occur with Sandberg bluegrass (Poa sandbergii), Indian ricegrass (Oryzopsis hymenoides), squirreltail (Sitanion hystrix), and species of Stipa being the most common. Shortly after the burn, standard crested wheatgrass (Agropyron desertorum) was seeded in the general area. Only a marginal stand was established. In some areas in the exclosure various wheatgrasses (Agropyron spp.) had been planted. There were also scattered stands of Wyoming big sagebrush (Artemisia tridentata ssp. wyomingensis) green rabbitbrush (Chrysothamnus visciflorus) and horsebrush (Tetradymia glabrata). The soils of the study area are derived from quartz diorite and are classified as Mollic Haplargids (Evans et al. 1967) and were characterized by Young and Evans (1974).

From about 1890 until 1920 Medell Flat was used in the spring and fall by range sheep operations, turning the area virtually into a dust bed at the turn of the century (Kennedy and Doten 1901). From 1920 until 1978 the area was subject to very severe, year-long grazing and in 1978 was put in a three pasture, rest-rotation grazing system. When grazed, (April 1 to December 31, second year and July 15 to December 31 , third year) the stocking rate was 3.85 ha (9.5 acre)/animal unit (cows) month.

\section{Measurements}

Vegetation and the associated VAM mycoflora was sampled during the second year (June 1982) of the three-year grazing cycle in a grazing exclosure (approximately 2 ha, constructed in 1963) and in the surrounding grazed land. All plants except redstem filaree (Erodium circutarium) and Sandberg bluegrass were sampled for density in 10 quadrats $\left(10 \mathrm{~m}^{2}\right)$ on both sites. One plant of each species was collected from each of the 10 quadrats inside and outside the exclosure for the determination of VAM-fungal colonization and plant dry weights. Roots of needle-and-thread grass (Stipa comata) and squirreltail (Sitanion hystrix) were excavated to a depth of $30 \mathrm{~cm}$, and roots of the forb tapertip hawksbeard
(Crepis acuminata) to $60 \mathrm{~cm}$. Roots and shoots of these plants were oven-dried at $70^{\circ} \mathrm{C}$ for 2 days. Dry weights were used to determine root dry-weight ratios (grazed/ungrazed) and root/shoot ratios for grazed or ungrazed plants.

The intensity of VAM-fungal colonization (percentage of root length infected) was determined by staining and evaluated according to Bethlenfalvay and Yoder (1981). To establish intra-species variation in the intensity of colonization, all 10 samples of 2 grasses (cheatgrass and needle-and-thread grass) and of 2 forbs [tapertip hawksbeard and desert phlox (Phlox austromontana)] were assayed individually for VAM fungi. The roots of the remaining plant species were not evaluated individually. Root systems of all 10 specimens of a species were pooled, cut in $1-\mathrm{cm}$ sections, and dispersed in water. Root segments were selected at random for the evaluation procedure, and it was assumed that variability within grasses or forbs would be similar to that for the species assayed in detail. Statistical differences between VAM-fungal colonization of plants from grazed or ungrazed areas were determined by student's $t$-test.

Taxonomic identification of VAM fungi was preceded by culturing the fungi in a medium of perlite and nutrient solution with sorghum (Sorghum bicolor) as the host plant. The fungal inoculum was made up of pooled soil and root samples from all plants, and was mixed with the perlite $(1 / 1, v / v)$. Inocula from inside and outside the exclosure were cultured separately. Roots and growth medium were assayed for VAM fungi after 4 months of growth in a greenhouse equipped with supplementary lights providing a photosynthetic photon flux density of $400 \mu \mathrm{molom}^{-2} \circ \mathrm{s}^{-1}$ and extending daylength to $16 \mathrm{~h}$. Fungal spores isolated from soil and roots were identifed according to Trappe (1982).

Soil was tested for available ( $\mathrm{NaHCO}_{3}$-extractable) $\mathbf{P}$ content according to Watanabe and Olsen (1965) at depths of 5 to 13 and $27-35 \mathrm{~cm}$. Four samples, pooled from 24 field replications, were analyzed. Samples at each depth were taken from inside and outside the exclosure.

Table 1. Floristic composition and species density of range plants near Reno, Nevada. Vegetation was surveyed in an ungrazed (19 yr) exclosure and in the heavily grazed surrounding area.

\begin{tabular}{|c|c|c|c|c|}
\hline \multirow{2}{*}{ Family } & \multirow[b]{2}{*}{ Species } & \multicolumn{2}{|c|}{ Density (plant $\left./ 10 \mathrm{~m}^{2}\right)^{1}$} & \multirow[b]{2}{*}{$\begin{array}{l}\text { VAM } \\
\text { colonization }\end{array}$} \\
\hline & & $\begin{array}{l}\text { ungrazed }^{2} \\
\bar{x} \pm \text { S.D. }\end{array}$ & $\frac{\text { grazed }^{3}}{x} \pm$ S.D. & \\
\hline \multirow[t]{6}{*}{$\overline{\text { Compositae }}$} & Erigeron linearis & - & $3 \pm 13$ & + \\
\hline & Chrysothamnus visciflorus & $2 \pm$ & $10 \pm 9$ & + \\
\hline & Tetradymia glabrata & $1 \pm 1$ & $1 \pm 4$ & + \\
\hline & Crepis acuminata & $69 \pm 26$ & $13 \pm 20^{*}$ & + \\
\hline & Lygodesmia spinosa & - & $30 \pm 38$ & + \\
\hline & Artemisia tridentata & $1 \pm 1$ & $3 \pm 4$ & + \\
\hline \multirow[t]{2}{*}{ Cruciferae } & Descurainia pinnata & $17 \pm 14$ & $19 \pm 9$ & +4 \\
\hline & Sysimbrium altissimum & $14 \pm 10$ & $16 \pm 5$ & - \\
\hline \multirow[t]{8}{*}{ Gramineae } & Agropyron intermedium & $29 \pm 50$ & - & + \\
\hline & Bromus tectorum & $1581 \pm 546$ & $526 \pm 227^{*}$ & + \\
\hline & Oryzopsis hymenoides & $8 \pm 2$ & $4 \pm 4$ & + \\
\hline & Stipa comata & $9 \pm$ & $3 \pm \quad 2 *$ & + \\
\hline & Sitanion hystrix & $15 \pm$ & $3 \pm \quad 3 *$ & + \\
\hline & Agropyron desertorums & $11 \pm$ & $2 \pm$ & + \\
\hline & Stipa thurberiana & $12 \pm 7$ & $2 \pm \quad 3^{*}$ & + \\
\hline & Agropyron trichophorum & $27 \pm 55$ & - & + \\
\hline \multirow[t]{2}{*}{ Leguminosae } & Astragalus sp. & $3 \pm 4$ & $15 \pm 7^{*}$ & + \\
\hline & Lupinus sp. & - & $6 \pm 7 *$ & + \\
\hline Polemoniaceae & $\begin{array}{l}\text { Phlox austromontana } \\
\text { Leptodactylon pungens }\end{array}$ & $\begin{array}{c}26 \pm 40 \\
-\end{array}$ & $\begin{array}{r}29 \pm \\
6 \pm 5\end{array}$ & + \\
\hline
\end{tabular}

1 Means and standard deviations based on ten quadrats, each $10 \mathrm{~m}^{2}$.

2Species shown as missing were not found in the grazing exclosure.

3Species shown as missing were introduced in the exclosure by seeding and were not present outside.

Trace infection of the rootips only in tansy mustard. Colonization was not quantified in the legumes.

s'Seeded inside and outside the exclosure.

*Indicates significant differences between plant densities on grazed or ungrazed sites by student's $t$-test $(\boldsymbol{P}<0.05)$. 


\section{Results}

\section{Effect of Grazing on Plants}

Elimination of grazing from a portion of the rangelands at Medell Flat resulted in a shift in vegetation within the grazing exclosure (Table 1). Certain plant species either did not occur in the exclosure [fleabane (Erigeron linearis), lupine (Lupinus sp.), prickly phlox (Leptodactylon pungens), and thorny skeleton plant (Lygodesmia spinosa)] or had considerably lesser density [Wyoming big sagebrush, green rabbit brush, horsebrush, and locoweed (Astragalus sp.)]. The density of other species [tapertip hawksbeard, standard crested wheatgrass ( $A$. desertorum), cheatgrass, Indian ricegrass (Oryzopsis hymenoides), squirrel tail, needle-andthread grass, and Thurber's needlegrass (Stipa thurberiana)] was significantly higher in the exclosure than in the surrounding grazed land. A few species [desert phlox, tansy mustard (Descurainia pinnata)] and tumble mustard (Sysimbrium altissimum) did not show a response to grazing. Amur intermediate wheatgrass (Agropyron intermedium) and Tobar pubescent wheatgrass (Agropyron trichophorum) were seeded only inside the exclosure and did not serve for grazing comparison.

Grazing had a dramatic effect on the grasses in the area sampled. Within the exclosure bunchgrasses had full tufts with hundreds of well-developed leaf blades while under grazing leaf blades were small, sparse, and restricted to the perimeter of the bunch (Fig. 1). The root systems of bunchgrasses declined in weight under grazing but did not suffer a decrease comparable to the shoots (Table 2). Grazing had little effect on the palatable forb (tapertip hawksbeard). These plants were of the same size in- and outside the exclosure (Table 2), but were much reduced in number on the outside (Table 1).
Table 2. Root dry weight and root/shoot ratio comparisons as a result of grazing. Root dry weight ratios (grazed/ungrazed) express the decline in root development in the grazed area relative to that in the exclosure.

\begin{tabular}{lccc}
\hline \hline & \multicolumn{3}{c}{ Species } \\
\cline { 2 - 4 } Parameter & $\begin{array}{l}\text { Needle-and- } \\
\text { thread grass }\end{array}$ & $\begin{array}{l}\text { Squirrel } \\
\text { tail }\end{array}$ & Hawksbeard \\
\hline $\begin{array}{l}\text { Root dry weight ratio } \\
\text { Root/shoot ratio }\end{array}$ & 0.48 & 0.53 & 0.95 \\
$\quad \begin{array}{l}\text { ungrazed } \\
\text { grazed }\end{array}$ & 1.2 & 1.1 & 0.6 \\
\hline
\end{tabular}

'Numbers are calculated from means of ten replications.

\section{Effect of Grazing on Mycorrhiza and Soil $\boldsymbol{P}$}

Grazing significantly decreased VAM colonization of all grasses, in some cases by more than $50 \%$ (Table 3 ). With broadleaf species, grazing had no significant effect on the extent of colonization. Only one VAM-fungal species, Glomus fasiculatum (Thaxt. sensu Gerd.) Gerd. \& Trappe (Gerdemann and Trappe 1974) (Fig. 2), was found in the grazed area. Within the exclosure a second species, Glomus clarum Nicol. \& Schenck (Nicolson and Schenck 1979) was also present. Concentrations of available $\left(\mathrm{NaHCO}_{3}\right.$-extractable) $P$ were similar at a depth of 5 to $13 \mathrm{~cm}$ inside and outside the exclosure (10.2 and $10.4 \mu \mathrm{g} \mathrm{P} / \mathrm{g}$ soil, respectively). At a depth of 27 to $35 \mathrm{~cm}$, however, $\mathrm{P}$ concentrations were significantly $(p<0.05)$ higher on grazed land $(6.0 \mu \mathrm{g} \mathrm{P} / \mathrm{g}$ soil) than inside the exclosure (3.7 $\mu \mathrm{g} \mathrm{P} / \mathrm{g}$ soil).

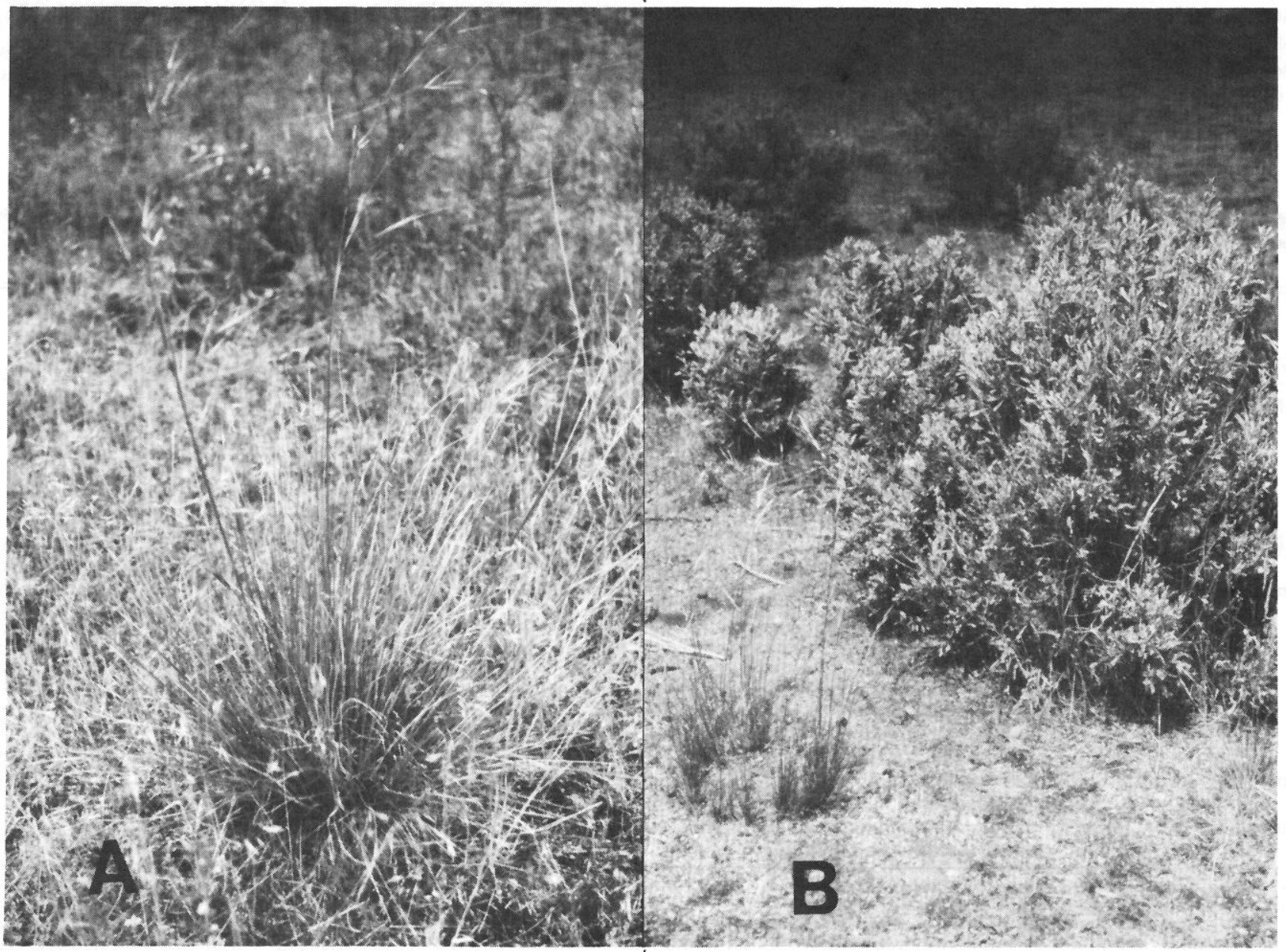

Fig. 1. A. Needle-and-thread grass in a grazing exclosure. Plants in the exclosure were not subject to grazing for 19 yr. B. Needle-and-thread grass subject to heavy grazing. 
Table 3. Colonization of range plants by vesicular-arbuscular mycorrhizal (VAM) fungi near Reno, Nevada during June 1982.

\begin{tabular}{llll}
\hline \hline \multirow{5}{*}{ Family } & & \multicolumn{2}{c}{$\begin{array}{c}\text { VAM colonization } \\
(\%)^{1}\end{array}$} \\
\cline { 3 - 4 } Compositae & Species & ungrazed grazed $^{2}$ \\
& Erigeron linearis & - & 47 \\
& Chrysothamnus visciflorus & 46 & 45 \\
& Tetradymia glabrata & 25 & 26 \\
& Crepis linearis & $47 \pm 14$ & $40 \pm 11$ \\
& Lygodesmia spinosa & - & 67 \\
Gramineae & Artemisia tridentata & 27 & 25 \\
& Agropyron intermedium & 85 & - \\
& Bromus tectorum & $76 \pm 10$ & $33 * \pm 9$ \\
& Oryzopsis hymenoides & 86 & $40^{*}$ \\
& Stipa comata & $82 \pm 9$ & $33^{*} \pm 9$ \\
& Sitanion hystrix & 83 & $53^{*}$ \\
& Agropyron desertorum & 88 & $63^{*}$ \\
& Stipa thurberiana & 88 & $40^{*}$ \\
Polemoniaceae & Agropyron trichophorum & 96 & - \\
& Phlox austromontana & $63 \pm 14$ & $54 \pm 10$ \\
& Leptodactylon pungens & - & 57 \\
\hline
\end{tabular}

'Percent colonization expressed as proportion of root length infected.

${ }^{2}$ Ungrazed plants were located in a 19 year exclosure.

*Significance at the $5 \%$ level.

\section{Discussion}

The VAM-fungal symbiont is dependent on photosynthate availability (Bethlenfalvay and Pacovsky 1983, Daft and ElGiahmi 1978), and clipping or grazing of the host plant has an adverse effect on its development (Wallace 1981). The inhibition of VAM-fungal colonization of grasses in this study can thus be ascribed to the reduction of the foliage under grazing, and to the concomitant shift in root/shoot ratios. The high root/shoot ratios produced by grazing indicate that source capacity in grazed plants may be insufficient to satisfy sink demand for photosynthates by the relatively large root system and the fungal endophyte. Although roots were not completely excavated, it is estimated that $85 \%$ of the total root mass of the grasses was retrieved (Weaver 1950) providing adequate comparison for grazing effects.

While positive effects of VAM fungi on individual physiological processes of the host, such as water relations and photosynthesis, have been reported (Allen et al. 1981), the mechanism of the relationship between VAM fungi and grazing and its impact on the arid-range ecosystem is still hypothetical (Wallace 1981). Correlations between grazing intensity and mycorrhizal infection have rarely been made (Davidson and Christensen 1977, Wallace 1981) and are difficult to interpret, as such evaluations are almost exclusively based on VAM-fungal colonization of the root cortex. This, however, is a less reliable measure of symbiotic effectiveness than the development of an extensive extraradical VAM-fungal mycelium (Bethlenfalvay et al. 1982, Graham et al. 1982), and its affinity for P absorption (Cress et al. 1979). The relevance of VAM fungi to soil structure formation and stability (Sutton and Sheppard 1975, Trappe 1981) and to the revegetation of disturbed lands (Reeves et al. 1979) is beginning to be appreciated. Other functions such as an effect on seedling establishment, soil permeability to water and soil deterioration due to compaction are likely and should be investigated.

The effect of the decrease in VAM-fungal colonization on the $P$ nutrition of the grazed plants was not determined in this study. However, as plant-available soil P levels were low (between 4 to 10 $\mu \mathrm{g} \mathrm{P} / \mathrm{g}$ soil) and within the range (4 to $12 \mu \mathrm{g} \mathrm{P} / \mathrm{g}$ soil) where growth enhancement due to VAM fungi was previously shown to occur (Bethlenfalvay et al. 1983), one may conclude that plants under grazing with low levels of VAM-fungal colonization were also deficient in $\mathrm{P}$ and suffered growth depression relative to nongrazed plants.

The absence of $G$. clarum from the pooled inoculum collected from all plants outside the exclosure indicates a severe reduction (or elimination) of this species of VAM fungus under conditions produced by grazing pressure. It may be inferred that $G$. clarum is more sensitive to photosynthate stress than G. fasciculatum, which may outcompete and displace the former when carbohydrates are limiting. Thus, grazing appears to cause not only a shift in the composition of the vegetation but also in the accompanying mycoflora.

\section{Literature Cited}

Allen, M.F., W.K. Smith, T.S. Moore, Jr., and M. Christensen. 1981. Comparative water relations and photosynthesis of mycorrhizal and nonmycorrhizal Bouteloua gracilis H.B.K. Lag ex Stend. New Phytol. 88:683-693.
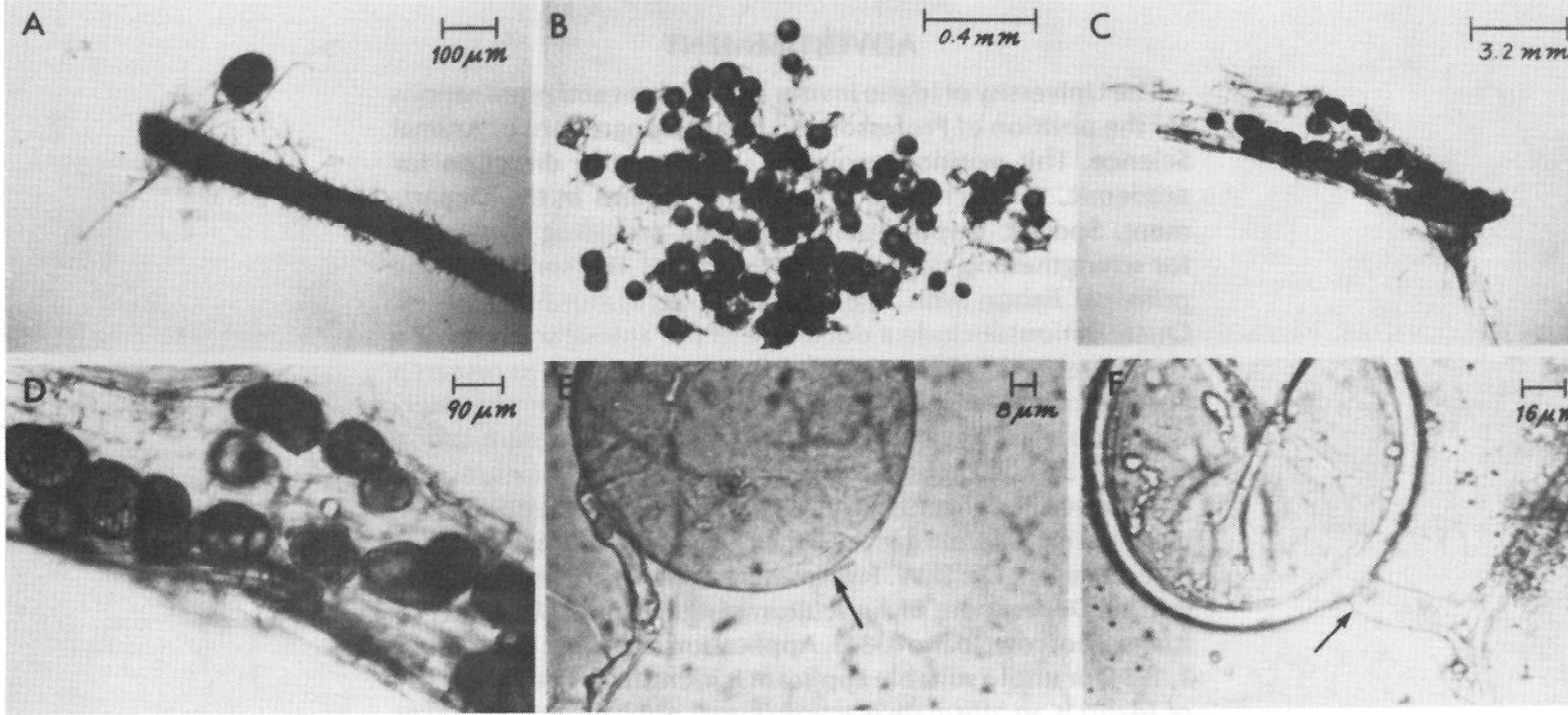

Fig. 2. Glomus fasciculatum, the dominant speceis of vesicular-arbuscular mycorrhizalfungusfound at Medell Flat near Reno, Nevada. A-root segment with extraradical hyphae and spore, B-loose sporocarp showing extraradical hyphae and spores, $C$ and $D$-root segment with intraradical hyphae and vesicles, $G$ and $F$-some species characteristics of $\mathrm{G}$. fasciculatum: double wall $(E)$ and constriction of hyphal attachment $(F)$. 
Bethlenfalvay, G.J., and J.F. Yoder. 1981. The Glycine-Glomus-Rhizobium Symbiosis. I. Phosphorus effect on nitrogen fixation and mycorrhizal infection. Physiol. Plant. 52:141-145.

Bethlenfalvay, G.J., M.S. Brown, and R.S. Pacovsky. 1982. Relationship between host and endophyte development in mycorrhizal soybeans. New Phytol. 90:537-543.

Bethlenfalvay, G.J., H.G. Bayne, and R.S. Pacovsky. 1983. Parasitic and mutualistic associations between a mycorrhizal fungus and soybean: The effect of phosphorus on host plant-endophyte interactions. Physiol. Plant. 57:543-548.

Bethlenfalvay, G.J., and R.S. Pacovsky. 1983. Light effects in mycorrhizal soybeans. Plant Physiol. (in press).

Cannell, G.H., and L.V. Weeks. 1978. Erosion and its control in semi-arid regions. In: G.H. Cannell (ed.) Agriculture in Semi-Arid Environments. Springer-Verlag, Berlin.

Cress, W.A., G.A. Thomeberry, and D.L. Lindsey. 1979. Kinetics of phosphorus absorption by mycorrhizal and nonmycorrhizal tomato roots. Plant Physiol. 64:484-487.

Daft, M.J., and A.A. El-Giahmi. 1978. Effect of arbuscular mycorriza on plant growth. VIII. Effects of defoliation and light on selected hosts. New Phytol. 80:365-372.

Davidson, D.E., and M. Christensen. 1977. Root-microfungal and mycorrhizal associations in shortgrass prairie. p. 279-287. In: J.K. Marshall (ed.) The Belowground Ecosystem: A Synthesis of Plant-Associated Processes. Range Sci. Dep. Sci. Ser. No. 26, Colorado State Univ. Fort Collins, Colo.

Evans, R.A., R.E. Eckert, Jr., and B.L. Kay. 1967. Wheatgrass establishment with paraquat and tillage on downy brome ranges. Weed. Sci. 15:50-55.

Evans, R.A., and J.A. Young. 1977. Weed control-revegetation systems for big sagebrush-downy brome systems. J. Range Manage. 30:331-336.

Gerdemann, J.W., and J.M. Trappe. 1974. The Endogonaceae of the Pacific Northwest. Mycologia Memoirs No. 5.

Graham, J.H., R.G. Linderman, and J.A. Menge. 1982. Development of external hyphae by different isolates of mycorrhizal Glomus spp. in relation to root colonization and growth of Troyer citrange. New Phytol. 91:183-189.

Hays, R., C.P.P. Reid, T.V.St. John, and D.C. Coleman. 1982. Effects of nitrogen and phosphorus on blue grama growth and mycorrhizal infection. Oecologia (Berl.) 54:260-265.

Jehne, W., and C.H. Thompson. 1981. Endomycorrhizae in plant colonization on coastal sand-dunes at Cooloola, Queensland. Austr. J. Ecol. 6:221-230.
Kennedy, P.B., and S.B. Doten. 1901. A preliminary report on the summer ranges of western Nevada sheep. Nevada Agr. Exp. Sta. Bull. 51.

Lorenz, R.J. 1970. Response of mixed prairie vegetation to fertilization and harvest frequency. Doctoral Diss., North Dakota State University, Fargo.

Mosse, B. 1973. Advances in the study of vesicular-arbuscular mycorrhiza. Annu. Rev. Phytopathol. 11:170-196.

Nicolson, T.H., and N.C. Schenck. 1979. Endogonaceous mycorrhizal endophytes in Florida. Mycologia 71:178-198.

Reece, P.E., and C.D. Bonham. 1978. Frequency of endomycorrhizal infection in grazed and ungrazed blue grama plants. J. Range Manage. 31:149-151.

Reeves, F.B., D. Wagner, T. Moorman, and J. Kiel. 1979. The role of endomycorrhizae in revegetation practices in the semi-arid West. I. Comparison of incidence of mycorrhizae in severely disturbed vs. natural environments. Amer. J. Bot. 66:6-13.

Snellgrove, R.C., W.E. Splittstoesser, D.P. Stribley, and P.B. Tinker. 1982. The distribution of carbon and the demand of the fungal symbiont in leek plants with vesicular-arbuscular mycorrhizas. New. Phytol. 92:75-87.

Sutton, J.C., and B.R. Sheppard. 1975. Aggregation of sand-dune soil by end omycorrhizal fungi. Can. J. Bot. 54:326-333.

Trappe, J.M. 1981. Mycorrhizae and productivity in arid and semiarid rangelands. p. 581-599. In: J.T. Menassah and E.J. Briskey (eds.) Advances in Food Producing Systems for Arid and Semiarid Lands. Academic Press, New York.

Trappe, J.M. 1982. Synoptic keys to the genera and species of zygomycetous mycorrhizal fungi. Phytopathology 72:110-1108.

Wallace, L.L. 1981. Growth, morphology and gas exchange of mycorrhizal and nonmycorrhizal Panicum coloratum $\mathrm{L}_{\text {., a }} \mathrm{C}_{4}$ grass species, under different clipping and fertilization regimes. Oecologia (Berl.) 49:272-278.

Watanabe, F.S., and S.R. Olsen. 1965. Test of an ascorbic acid method for determining phosphorus in water and $\mathrm{HaHCO}_{3}$ extracts from soil. Soil Sci. Soc. Amer. Proc. 29:677-678.

Weaver, J.E. 1950. Effects of different intensities of grazing on depth and quantity of roots of grasses. J. Range Manage. 3:101-113.

Young, J.A., and R.A. Evans. 1974. Population dynamics of green rabbit bush in disturbed big sage brush communities. J. Range Manage. 27:127-132.

\section{ADVERTISEMENT}

The University of Idaho invites applications and nominations for the position of Professor and Head, Department of Animal Science. This position provides administrative direction for academic, research, and extension programs in the Department. Specific responsibilities include providing leadership for strengthening departmental programs and serving as the principal liaison with Idaho's animal agricultural industries. Qualifications include a doctorate in the animal sciences or a closely related field and a record of achievement in research and education. Applicants must provide evidence of leadership, program development, and effective communication abilities. Salary will be commensurate with qualifications and experience. Applicants should submit a letter of application, current curriculum vitae, and the names and addresses of four references to: Dr. D.W. Fitzsimmons, Chairman, Search Committee, Department of Agricultural Engineering, University of Idaho, Moscow, Idaho 83843. Application deadline: September 1,1984 , or until a suitable applicant is identified. The University of Idaho is an affirmative action/equal opportunity employer and educational institution. 